\title{
Anthroponyms and Microtextology of Literary Text
}

\author{
Gulshat Zinnatullina,
}

EDP Sciences, A.N. Tupolev National Research Technical University of Kazan - KAI, Russia

\begin{abstract}
This article deals with the basic types and functions of adjective constructions "accompanying" proper names in the literary text. This article continues research in the field of poetic onomastics. Stories and short novels by canonical Tatar writers such as A. Yeniki, M. Amir and F. Khusni served as a material for research. The object of study is anthroponyms and their immediate environment (appellatives and their combination with proper names). The novelty and topicality of the research can be attributed to the fact that it is the first attempt to study anthroponyms in particular in combination with different appellative constructions. This, in its turn, allows us to consider anthroponyms as an important structure-forming element of the literary space. The research of the onomastic layer of the literary texts, which we chose, enabled us to draw conclusions about the wide use of dependent words (they are often participles and participial constructions) amid anthroponyms. We make an attempt to reveal the peculiarities of the use and functions of such constructions within the framework of this article. It has turned out that they may contain the most significant, comprehensive information on any character. In addition, these combinations serve as vivid expressive means, reflect specificity of the writer's artistic and creative thinking.
\end{abstract}

Linguistic devices of the literary texts have been studied intensively over the past decades. Nevertheless, there has been a tendency to increase attention to the problems of peculiarities of proper names functioning in the literary space. Poetic onomastics is a topical and actively investigated field of onomastics in the modern Tatar language study. The article by G.F. Sattarov dedicated to the analysis of the onomastic layer in the works written by G. Ibragimov marked the beginning of this direction development. The period of system monographic study of proper names poetics begins with the works by R.Kh. Garrapova, A.R. Biktimirova, V.M. GaripovaKhasanshina, S.S. Arslanova, G.Kh. Zinnatullina. These works explore the peculiarities of functioning of onomastic categories in the linguistic and poetic structure of the literary text.

The analysis of artistic work anthroponymic system allows to state the fact that the study of literature anthroponym functions, demands first of all to take into account the diversity of complex interactions and relationships. During the interpretation of a main idea and the aim of a work creation it is impossible to ignore the problem of destiny, the peculiarities of functioning in a text and personal names. The issue of anthroponym functioning in a text was and remains a controversial one. This is due to the fact that each researcher interprets the functional aspect of an anthroponymic system of works on his own. Therefore, you must start from the general properties common to all elements (in this case poetic names) of an artwork. Proper names are an object of a multifaceted study for several decades. And today onyms give an inexhaustible impetus for their study as an interdisciplinary phenomenon, combining the facts of history, culturology, linguistics, psychology, and so on.

Having imagined an overall picture of proper names, of onomastics and its directions, we consider it is necessary to analyze the issue of onomastic space - one of the newest areas in modern onomastics. Onomastic space is a time continuum that exists in the presentation of people from different cultures and it filled differently in different epochs. Onomastic space is presented in fragments within the mind of every person. It is quite fully revealed only during a special study.

The center of onomastic field is represented "by the core negligible in terms of its constituent element amount; there is a perinuclear space, periphery next to it, which has a zonal structure - it has close, distant and extreme zone. This structure is characterized by sufficient stability, durability, but at the same time, it is not devoid of functional mobility.

Peripheral position in any language onomastic space is occupied by the classes of onyms, which call not always clearly limited material objects, sometimes even a series of objects that are identical or united by a common theme or idea. It is obvious that in these areas the properties of a proper name are expressed not so bright. They acquire their particular developments invalid in an onomastic space nucleus.

In our view, all the abovestated provisions about onomastic space and onomastic field are also applicable in respect of works of art. However, when it comes to the onomastic space of literary texts, it is necessary to take into account the fact that very often an important role in the reconstruction of the author's picture of the world is played by microtoponyms and not 
anthroponyms. Microtoponyms appear and function in popular speech, their purpose is the nomination of natural landscape objects in the vicinity of a village, they are specific, usually simple by structure and are correlated with the literary language words. According to our research, microtoponyms can perform nuclear omonym functions sometimes, in particular act as a keyword (see M. Amir's novel "Agidel").

Anthroponymic system of fiction is made up of different layers, however they all share one base - the development of a product theme and idea. Based on the role performed by anthroponyms in the disclosure of a literary text idea, they can be considered in two aspects:

1. The names of literary characters who are directly involved in depicted events. They, in its turn, are subdivided into 1) the names of the main characters, and 2) the names of episodic characters.

2. Anthroponyms, applied beyond a work plot and developing its artistic and poetic layer. In our works these are the names of historical figures and the names of the religious-mythological character.

In accordance with the field structure of artistic work onomastic space, we think it is possible to consider the submitted anthroponym groups in a nuclear-peripheral projection. During a detailed consideration the names of the main characters form the core of all onomastic material used in texts. The names of episodic characters develop the perinuclear space of a text. Accordingly anthroponyms, used beyond a work plot represent the periphery of a literary text onomastic space.

Protagonist names. 1119 anthroponyms were recorded in studied works. The largest number of anthroponyms was used in the memories of A. Eniki "Soygy kitap" ("Pages of the past") - 352; in M. Amir's trilogy "Saf kүңеl" ("Pure Soul") - 173; in F. Husni's novel "Utyzynchy el" ("The thirtieth year") - 96. The names of main characters make up $4.5 \%$ of the proper name total number. Despite their small number, it turned out that this layer of anthroponyms bears an ideological burden and that they have a text-forming function of a name. The selection of protagonist names plays a crucial role in the development of a unique, bright, artistic image.

According to our observations, writers guided by the realities of the period which they depict in their works during the selection of the main character names. The thing is about the correspondence of selected names to the anthroponomical system of depicted period, taking into account all of its cultural and historical features. This layer of names is characterized by phonetic, semantic and poetic motivation. It should be noted that the semantic motivation of names is used in the works of our authors most often. This type of motivation is possible by using the names with a bright value existing prior to anthroponymic one: Gomər ("Life and longevity") - "In an hour", Zefər ("winner reaching the goal") - "Mirage", Safina ("purity, unselfishness") "Mirage", Kamil ("perfect") - "Pure soul", Vəsilə ("the one who is able to wait") - "Ring", Gayaz ("energetic, fiery") - "Agidel" and others.

They also use actively the phonetic-metaphorical motivation of proper names: Rəshidə (// rəshə - "haze")
- "Mirage", Mərvər (// mərmər - "marble") - "Night drops" Geləndəm (// gel - "Flower", beautiful like a flower) - "Memories Gulyandam", Akəbi (// ak "white, clean") - "An unspoken testament", Zehrə (zehrə yoldyz // // the brightest star) - "heart secret", Sania (// saf // Saf kүңеl // - "clean, pure soul") - "pure soul". As the examples show, the phonetic sound of these anthroponyms is consonant with certain concepts that define the role of the characters in a text, open a work idea. The phonosemantic peculiarities of onyms turn them into an important component of a work of art structure, making them an additional detail in the characterization of images. That is why this type of personal names is the category, which reflects an author's own position. Also the following fact is important: the names of the main characters are the popular, traditional names of Tatar anthroponymycon (except for the anthroponym Akəbi). In spite of this, each of them is realized as an individual, original means in an artistic image creation.

Episodic character names. This stratum of literary onyms makes more than $90 \%$ of all studied anthroponymic system of works. The main feature of the secondary character names is that they are characterized by cultural and historical motivation. In other words, when you select this group writers are guided primarily by such parameters as ethnicity, social status, the origin of characters, an era in which they live and operate. That is why the use of such personal names that correspond to the most to a pictured period can reflect not only national, but also territorial peculiarities as a rule. As they mentioned in the previous paragraph, an anthroponymic system of a given period has some features. This is reflected in the genetic composition of onym structure. But all these nuances are fully manifested precisely in the names of episodic characters.

In the course of our study it became clear that the names of the minor characters are able to perform a variety of artistic and aesthetic functions:

1) Personal names appearing in the speech of main characters or an author's speech, ensure the continuity of a statement: "Хәзер дә ул ераклаша барган авыл очына, Заһидә күренмәсме дип, һаман карый бара, ләкин юл буш, авылдан ашыгып килүче күренми иде" (And now he goes and looks back at a receding countryside, looking back for Zahida. But the road is empty, there is no one who would quickly walked from the village). "Бүгенгедәй күз алдында: өстенә утыртма якалы озын кара кәзәки, башына кырын салып кырпу бүрек кигән, сызылып кына чыккан кара мыеклы Тимержан шушы ишегалдында үзенең Зәйтүнәсен сул кулыннан тотып тарантастан ак киез өстенә төшергән иде, hәм Зәйтүнә йомшак ак киез өстеннән атлап, менә шушы өйгә аларның килене булып кергән иде" (He remembers it like today: in the same yard Timerdzhan wearing a black long Cossack clothes with stand-up collar, with a thin strip of black mustache dropped his Zaytuna on a white felt. And Zaytuna, passing on this white felt, came in the same house as their daughter in law).

2) The names of the characters are widely used in various comparisons: “...Ике бертуган, әмма никадәр 
зур аерма! Нигъмәтулла дәдәкай урта буйлы, таштай тыгыз, какча гәүдәле, ә Мөхәммәдъяр дәдәкай буйга да кечерәк, гәүдәгә дә юанрак" (There is a big difference between two brothers! Uncle Nigmatulla is of medium height, strong as a rock, thin, and uncle Muhammadyar and is small and has an overweight body). "Исем-фамилияләре охшаган булса да, Камәлетдин белән Камәретдин холыклары ягыннан бөтенләй икесе ике төрле кеше" (Despite the similarity of names and surnames, Kamaletdin and Kamaretdin are quite different people by nature).

According to the abovementioned examples, the anthroponymic system of works studied by us is characterized by versatility and originality. It reflects the national characteristics and the mentality of Tatar people.

Anthroponyms used outside a work plot. As we noted above, this group of anthroponyms forms an artistic and poetic layer of works, they are directly involved in the creation of stylistic figures and poetic methods. Typically, this layer of anthroponyms is used to create symbolic images or as a part of idioms. Compare: “Алар да, Ишәй белән Кушай шикелле, каяндыр юллар буеннан абына-сөртенә килеп чыктылар" (They are like Ishayu and Kushayu, appeared from somewhere along the roads stumbling). "Иртәгесен кайтып керешкә өйдә кубыпмы-куба Сафура бураннары" (A storm is raging tomorrow morning (literally - "Safura storm"). The phrase "Safura storms", denoting a strong contention, given in honor of a scandalous woman Safura, found in another work written by F.Husni: "Иртән кузгалган Сафура буранын оныткан, атны житәкләп ишек алдына килеп керүгә, бар тавышына кычкырып жибәрде..." (Having forgotten about the morning scandal, entering into the yard with a horse, he immediately cried out in a loud voice ...).

Also the works actively use the images of religious and mythological character. In particular, Gazrail's image can be named - an angel who takes the souls of men according to Islamic teachings; Prophet Mohammed and Satan (Iblis). Compare: "Болай ул, тиктомалдан гына килеп бервакытта да жаныңны алмыйлар. Газраил булып Газраил дә бусагаңнан сәлам биреп керер, ди" (So they never come for your soul without a reason. They say, Gazrail greets entering). "Ә баксаң, төшкә кергән дөя ул Газраил, имеш! Берәр якының үләргә булса, шул юаш хайван төшкә керә, имеш!” (And it turns out, that a dreamed camel is Gazrail! If someone from a family has to die, this harmless animal will appear in a dream).

According to the presented examples, the religiousmythological, literary anthroponyms (the images of popular literary works) occupy a special place in the anthroponymic system of works. Their main role is the transfer of ideas in an original way, the reflection of a national mentality, the ethnographic peculiarities of Tatar people. They are used as a means of emotionality and narrative imagery increase.

It is necessary to create a character's "profile" in the addressee's (reader's) consciousness for pragmatically correct combination of an adjective and an anthroponym into one nominal group. As it is known, a nominal group (NG) is a constituent, which possesses syntactical properties of a noun [1:36], [2]. It shall be noted that it is a general term, which is used along with such terms as "a substantive group" or "a nominal group". "According to unwritten rules of communication a speaker shall not disclose external and internal features of the subject without informing of subject's social status and relation to the speaker etc." [4:158].

A.D. Shmelev singles out the following three types of anthroponomic constructions and characterizes them briefly. Group 1: an adjective may express a characteristic provided by the speaker (characteristic of appearance, character traits, behavior etc.). Group 2: a function of an adjective is limited as either there are two or more persons with the same name in the general field of view (Volodya Senior and Volodya Junior), or it is necessary to highlight some period of a proper name bearer (previous, young). Various metaphorical uses of proper names, where an adjective "supports" this metaphoricity by means of incompatibility of its sense with "direct" understanding of the proper name (northern Orpheus type) refer to Group 3 [5:72-74]. We suppose that the functions of the adjective constructions (participles and participial constructions) that we consider together with anthroponyms are very similar to the role of adjectives considered by A.D. Shmelev. Let us consider these types in more detail.

1. Characteristics given by the speaker. I would like to mention that the features describing characters may be very different, from visual (... a daughter of pear-shaped Tonya) to acoustic (Noiseless Raisa Vasilyevna). As A.D. Shmelev notes "in all these cases, adjectives somehow compensate conceptual insufficiency of proper names, ensure semantic interaction of the whole nominal group with the context, specify what characteristics of a proper name bearer are substantial for the formation of the sense of a statement" [5:73].

The analysis of the works by Tatar classic writers under research allowed revealing the following features according to which characters are described. 1) Appearance, clothes of a character: “ ...Tире толып кигән Галәви абзый басыл тора" (Galyavi abzy wearing a sheepskin is standing right there)*. "Табынның хужсасы - чәчләрен уртадан ачып тараган бала чырайлы кыз Фәния икән” (Faniya, a girl parting her hair in the middle and having a babyface, was a hostess, who laid the table). 2) Character's place of living is specified. We would like to mention that there are a lot of constructions particularly of this type. [6:16]. Such form of personality characterization is actively used in the Tatar language, and is reflected in the fiction works: “Күрше кварталда үз өйләре белән яшәүче Баязит абзыйлар” (The family of Bayazit aby living in their own house in the neighborhood...). “Тегермән очындагы Наилә” (Nailya living near the mill...). “Үрдәк урамындагы Гафи абзый”. (Gaifi abzy living in the Duck Street...). Furthermore, there were combinations which served as predicates. “Госман, безнен курие малай” (Usman, our neighbors' son). 3) At the same time, character's place of birth and occupation are specified: “Шушы авылдан 
чыгып та, күрие авылдагы трактор паркында эиләүче механик Жаббар" (Jabbar, a mechanic, born and raised in this village, but working at the tractor fleet in the neighboring village...). "Вәсиләне Сатыш авылының кибетче Зариф малаена кияүгә биреп куйганнар" (Vasilya married to the son of Zarif, a salesman, from Satysh village). What is more, such combinations where any character's occupation, purpose of arrival to any place etc. is described in much detail are also highlighted. Compare: "Мех фабрикасында инженер бульп эиләгән Крысин" (Krysin working as engineer at the skinnery). Or: "мәктәп белән авыл советы өен жсыештыруцы Мәүлиха" (Maulikha, who worked as a cleaning lady in the school and at the office of the village council).... “Әле күптән түгел генә бу Әтәчле авылына уку өе мөдире итеп жсибәрелгән Котдус Вафин" (Kutdus Vafin recently sent to Petushki village to work as a chief of the village library and reading-room). "Иной ягыннан кардәи тиешле мин белгән Янгуразларның күбесе жсир эшен яратып, жсиелеп эиләүче таза тормышлы агайлар иде" (The most of the Yanguzarovs, my mother's relatives whom I knew, were people with a tidy farm and loved farming), “Ибрайның агасы өрлектәй таза Хәсән абзый танылган көрәчче иде”(Ibray's elder brother, a brawny fellow, was a well-known wrestler). The latter examples abound in all possible characteristics and serve as a vivid means of expression. 4) Character's description according to its place in a certain moment: "Тәрәзәгә кариы якта утырган Саттар башын тотыл изалана, аның бармак араларыннан кан бәреп чыккан" (Sattar, sitting in front of the window, is twisting with pain holding his head with the hands, the blood is running along his fingers). 5) Adjective combinations, which characterize a person by means of his/her living conditions. Such constructions are of interest because they draw reader's attention to the specific conditions and troubles the character has faced [7]. In addition, such characteristics contain author's attitude towards this specific person: "Хажсиның элекке хатыныннан калып,уги ана типкесе астында үскән кызы Нажсия бу хәлне һич тэ башына сыйдыра алмады" (It was beyond comprehension of Nadjiya, hajji's daughter from his first marriage, who grew up oppressed by her stepmother).

2. Constructions in which characteristics have metaphorical shade of meaning: "Юан беләкле, нәкъ капчык күтәрү өчен генә яралган таза хатын Мәймүнә" (Maymuna, a corpulent woman, seemed to be born for lifting bags). This construction implies physical power and dimensions which are unusual for a woman. Concurrently, two female characters are compared: delicacy and pint-sized body structure of Milyausha, a main female character, is emphasized. "Исемен атаганда да телеңне сындырырлык, Азоль дигән бер күсәк, рәттән өч көн дарескә килмәде”. (Azol, one can roll off the tongue pronouncing his name, once skipped classes for three days running). This case

All titles of the works are given in the end of list of references. demonstrates that this name is not traditional for the village in the late $80 \mathrm{~s}$, and implies this character's negative traits (a teenager from a troubled family who was neither keen-witted nor good-natured).

"Киндер күлмәкле Хәдичә торып торсын әле, анда мине, яшь тай төсле, ефәк чукларга күмелгән Вәсилә көтеп тора торгандыр"(Let Khadicha wearing a canvas dress wait, since Vasilya, who decorated herself with silk ribbons, is probably waiting for me) is a striking stylistic example, which emphasizes even with some sarcasm the advantage of one female character (Vasilya) over the other (Khadicha) for a narrator (Aidar). For this purpose, the author successfully used characteristics, which are connected with the appearance (in this case the appearance is a marker of characters' welfare). "Батталов бик жсанланыл, әлеге татлы телле Зөбәергә сорау кyйdbl.."(Battalov excitedly asked this sweet-mouthed Zubair a question). In this example a compound adjective, an epithet, sweet-mouthed, points to the peculiarity of the character's personality. This character never expresses his thoughts openly, can avoid contentious issues upon communication, at that, he applies actively his oratorical skills.

Toponymic adjectives and proper names

Such examples are characterized by figurative use of proper names in the function of the predicate, which requires introduction of special indicators, namely incompatibility of semantics of an attribute with a verbal understanding of an anthroponym.

However, toponymic (ottoponymic) adjectives in combination with anthroponyms did not always manifest themselves in the language as metaphors included in the text. A.B. Penkovsky found an interesting phenomenon connected with the use of such adjectives in the specialized "differential" function of an appositionattribute to personal and family proper names, "where they obtain a regular meaning "living temporarily or permanently among the people mentioned / in the country mentioned / on the territory mentioned. In terms of far-flung family ties peculiar to the Russian society of that epoch, such differentiating characterizing attributes would be a convenient and terse means of definition singling out of a needed person from the majority of his/her close and distant relatives and namesakes [9: 177].

Such phenomenon is very widely spread in the Tatar language. Toponymic attributes concretize a personality specifying his/her place of birth, living and work. Cities, villages, districts and etc. may act as the basis for such attributes. It is very interesting that in those works where the stories are set in the villages or rural areas, attributes containing the information on the home village of any character are used much more often (in comparison with the speech of urban dwellers): Бишбалтадагы Латыйn" (Latip living in Bishbalte), "Күллетүбә авылының Харис малае Рифгать Котльбаев (R. Kutlybaev, a son of Kharis from Kulletuba village), “Сатышиың Зарифы”" (Zarif who comes from Satysh village), “Алмалы авылындагы ялгыз карчык Хатирә ana" (a lonely old woman Khatira apa from Almaly). “Безнең Каргаль кызы Мәрзия апа" (Марзия апа из 
нашей деревни Каргалы) (Marziya apa from our village Kargaly), “Әлмәт ягы Өч Мунча авылыннан Борһан абзый" (Uncle Burkhan, born and raised in Uch Muncha village of Almetyevsk District) - a district is specified as there are several villages in Tatarstan having the same name. In other cases the attributes specifying a city or a street, where characters live, are used: "Казан еzеme Усман Шахиев" (A Kazan lad Usman Shakhiev) - said by a female character who was born and raised in Cheboksary; "Подлужныийдагы Хатирә" (Khatira living in Podluzhnaya street); “Чехов урамындагы Мисбаx" (Misbakh living in Chekhov street).

There also occur examples when ottoponymic attributes serve as the predicative position: “Әйләнеn карасам, Рахман абзый тора. Минем белән бергә килгән Кәче кешесе" (Turning his head, he saw uncle Rakhman, a man who came with me from Kachi village). "Шулай ук безнең кечкенә мәдрәсәдә дә якын-тирә авыллардан килеп укып ятучы малайлар да бар иде. Шулардан ике малай - Тазлар Дәүләкәненнән. (There were also young schoolchildren from neighbouring villages in our madrasah. Two of them are from Daulyakan)

Summing up, we would like to note the following. Out of three semantic factors, which, in opinion of E.M. Wolf, determine the role of adjectives in the text (such factors are a) semantics of the name attributed, b) semantics of the predicate and c) the role of the nominal group in the semantics of a statement as a whole), for "an adjective + proper noun" combinations the latter is crucial [8:125]. Only so-called compound proper names, which form an integral part with their attributes, are fully independent from the context. Here, an adjective essentially becomes closer in its function to a constant epithet, i.e. to an epithet, which is firmly connected with a noun or a verb, according to the function, and denotes "an attribute of object or action, which is normative in this world picture". [9: 117]. Thus, adjectives as characteristics given to the speakers, figuratively saying, "grow" out of the previous text. If we are to apply a classification offered by H. Kalverkaemper, who singled out two types of relationships of onyms in the text: those depending on the text and those constituting the text [10: 267], we have the first type of onyms in this case. If there is no context, characterizing attributes do not form the same nominal group with an anthroponym. It is necessary to note a number of adjectives, which can actualize metaphoric and metonymic plan of a nominal group. That fact that a proper noun bearer is a wellknown person is deemed to be an additional condition in this case.

To conclude, it should be noted that what was called microtextology of a name, i.e. the closest environment of the name in the text, is actually wider than a "micro" category as it seems to be directly connected with the main idea of the whole text. A proper name together with its appellative "accompanying" besides fulfilling a neutral informative and identifying function, may contribute to the increase of message influence taking part in the stylistic game. Thus, the combination of appellatives with proper names can become not only a stylistic device, but also an artistic device, which may form a world of the whole fiction work.

\section{References}

1. E.A. Lyutikova, Moscow University Mathematics Bulletin 9, 36 (2010)

2. B.Y. Norman, M.A. Plotnikova, Voprosy onomastiki 3, 84 (2017)

3. Z.F. Salakhutdinova, Z.F. Mirgalimova, R.I. Khaziev. World of Scientific Discoveries 3, 304 (2015)

4. O.P. Yermakova. Context-related Compatibility of Identifying Nouns with Adjectives, (Text Syntax, Nauka, 1979)

5. A.D Shmelev. Russian Language and Extralinguistic Reality, (Yazyiki slavyanskoy kulturyi, 2002)

6. G.K. Zinnatullina. Science review: humanities research 6, 116 (2016)

7. A.B. Penkovsky. On Two Types of Regular Polysemy in the Language of Pushkin Epoch. Name: internal structure, semantic aura, context. Theses of the international conference. Part 2, 176 (2001)

8. E.M Wolf. Adjectives in the Text. Linguistics and poetics (Nauka, 1979)

9. N.V. Vasilyeva, A Proper Name in the World of Text (Librokom, 2009)

10. H. Kalverkaemper Text linguistik der Eigennamen (Klett-Cotta, 1978) 